JMKSP (Jurnal Manajemen, Kepemimpinan, dan Supervisi Pendidikan)

Volume 6 Issue 2 (2021) Page 148-163

ISSN 2614-8021 (Online) 2548-7094 (Print)

\title{
The Management Orphanage in Henri Fayol's Perspective: A Case Study of Lembaga Kesejahteraan Sosial Anak Darul Hadlonah Ceper Klaten
}

\author{
Diah Novita Fardani ${ }^{1}$, Meiwatizal Trihastuti ${ }^{2}$, Umar Al Faruq A. Hasyim ${ }^{3}$ \\ ${ }^{1}$ Institut Agama Islam Negeri (IAIN) Surakarta, ${ }^{2}$ STKIP Pasundan Cimahi, \\ ${ }^{3}$ Insitut Agama Islam Ma'arif NU Metro Lampung \\ Corresponding Author E-mail: diahnovita.novy@gmail.com
}

Received 13 April 2021; Revised 16 April 2021; Accepted 20 April 2021

\begin{abstract}
This article was to find out the substance framework of Henry Fayol's theory, to know the application of management Lembaga Kesejahteraan Sosial Anak (LKSA) Darul Hadlonah Ceper Klaten, and to find out the relevance of Henry Fayol's managerial practice theory applied to the Orphanage LKSA Darul Hadlonah Ceper Klaten. The researchers used qualitative research. Observation and interviews was used in collecting the data. The results indicated that the implementation management Orphanage of LKSA Darul Hadlonah Ceper Klaten in the functions of planning, command or giving orders, coordinating and controlling were going well. The planning system was adjusted to the timeframe that would be needed. Hence, the implementation of planning management was running well. Being able to jointly be responsible with everything related to the utilization of facilities, equipment and personnel needed.
\end{abstract}

Keyword: Management Orphanage, Henri Fayol Theory, Management 


\section{Introduction}

Theoretically, management is a conceptualization of the study between the dimensions of behavior, system components, organizational change and development. The demands for change and development era were raised as a result of demands from the internal and external environment (Hezri, A. A., \& Dovers, S. R. 2013), which will have implications for changes in group behavior and the social environment (Gifford, R., \& Nilsson, A. 2014; Fu, H., \& Liu, X. (2017). The changes of this context aim as an effort to adapt to the environment, Hence, the organizational goals are in accordance with the needs or demands of society. Within this framework, an institution adapts to the environment, including adjusting technology and human resources.

Lack of human resources, financial capital and technology has caused a crisis impact on parents who experience economic downturn. As a result, it is the children who fall victim to a lack of education and welfare (Zaidi et al., 2019). The existence of an orphanage plays an important role in creating prosperity because the orphanage can seek to solve the problem of poverty and social inequality (Ruliana, 2014; Aziz, M. N., \& Mohamad, 2016). The orphanage is an institution to create children with good character and quality in the future. An orphanage that is managed with a trustworthy and professional system and management with guidance and supervision from the government and the community will trigger the survival of the community and at the same time make the social order healthier (White, D. 2003; Tengko, et al., 2021), thereby reducing the gap between the well-off and disadvantaged groups of people. There are many ways to save and protect them from violent immorality, for instance giving guidance, protection and provision of proper education through social institutions (Cahyono, et al., 2018; Amrizal, et al., 2020). It's clear that social institutions that look after and care for orphans, the poor or those who are neglected. Through orphanages, the poor or those who are neglected are the mandate and gifts of God Almighty (Masduki, 2020). There are inherent in dignity as a whole human being and at the same time as a successor to the ideals of the nation's struggle which has a strategic role that has special characteristics and characteristics and in turn can experience the continuity of the existence of the nation and state. Therefore they need to get the widest possible opportunity to grow and develop optimally either physically, mentally and socially and have noble and religious morals.

Today there are many orphanages, either under the auspices of the government or non-government, what distinguishes, it is how the orphanage is 
managed. According to Henry Fayol (Fayol, 1963) an organization can be said to be successful if it implements management principles. Good and directed management will greatly support the effectiveness of the goals of the orphanage (Nawawi, 2005; Gamayuni, 2018), namely by forming children with good character and quality. Maximum results cannot be achieved without a Management determination process carried out by the orphanage. In this case, the LKSA Darul Hadlonah Ceper Klaten Orphanage tries to manage well and be organized.

Lembaga Kesejahteraan Sosial Anak (LKSA) Darul Hadlonah Ceper Klaten Orphanage is a social institution that accommodates, fosters and cares for orphans, in Ceper village, Klaten city. LKSA Darul Hadlonah Ceper Klaten Orphanage assisting orphans that has been running for about ten years. In starting its activities, it coincided with the beginning of the new school year, the LKSA Darul Hadlonah Ceper Klaten Orphanage officially accepted foster children. This institution tried to integrate the parenting system and the education system, in the morning the children study on outside, namely in formal or public schools, while in the afternoon and evening the children are educated on religious and skills deepening with the guidance of caregivers from various Islamic boarding schools and colleges. Over time, of course, a single management is not enough to solve various problems that found in learning. For this reason, in order for the orphanage to become better and more professional in the future, it is necessary to carry out management which in essence is to carry out management functions which include planning, organizing, command, coordinating, and controlling or supervision is important to be fully implemented in the daily life of the orphanage (Bilal, M. Wasim, 2003; Tampubolon, 2020; Irianisyah, 2020).

This research was important to do for the development and existence of the orphanage in the future. Moreover, until now there has not found a standard pattern of orphanage management that is used as a reference for other orphanages. Therefore, by looking at the above conditions, the researchers consider it necessary to conduct research on the implementation of orphanage management in Ceper Klaten, with a case study on the management of the LKSA Darul Hadlonah Ceper Klaten Orphanage from Henri Fayol's perspective. The purpose of this study was to find out the substance framework of Henry Fayol's theory, to know the application of management LKSA Darul Hadlonah Ceper Klaten, and to find out the relevance of Henry Fayol's managerial practice theory applied to the Orphanage LKSA Darul Hadlonah Ceper Klaten. 


\section{Methods}

This research used qualitative methods. In collecting the data the researchers used observation, interviews and documentation. The method of observation is one of the methods used in research that makes it easier for researchers to find information. According to Nana Syaodih, the observation method is a technique collect data by observing each activity ongoing (Sukmadinata, 2013). The data included location and geographical conditions of environment the orphanage. Interview is a meeting of two people to exchange information and ideas through question and answer so that inner meaning can be constructed a certain topic (Sugiyono, 2016). In line with the opinion Prastowo, those interviews are used to collect data in the form of a meeting of two or more people directly for exchanging information and ideas with verbal question and answer (Prastowo, 2014).

The participants in interview was leadership, secretary and treasurer as information to collect data about how implementation of orphanage management of Lembaga Kesejahteraan Sosial Anak (LKSA) Darul Hadlonah Ceper Klaten. The documentation is a data collection step by examining and exploring existing literature, which can be in the form of scientific notes and documents (Sugiyono, 2016). The researchers used collecting the data source from journals, scientific articles, theses, dissertations and so on. It was done as an alternative reference material in the research being carried out, hence the researchers get more insights or an in-depth description of the research being carried out. The literature book in accordance with the author of the research that is written by Henri Fayol (1963) entitled "General and Industrial Management "The book discusses about the five management functions includes planning, organizing, command, coordinating, and controlling.

\section{Results and Discussion}

\section{Henry Fayol's Theory Substance Framework}

This research used Henry Fayol's Organizational Theory of management administrative. Henry Fayol's organizational theory is a classic theory that developed in 1952 1800's. Classical theorists emphasized the importance of "chains of command" and use discipline, rules and strict supervision to transform organizations to operate more efficient. 
Henry Fayol is one of the most influential contributors to the concept of management or modern administrative science as he is known as the "Father of Management." Fayol's most famous legacy concerns the five main functions of management, viz planning, organizing, mobilizing, monitoring and assessing. According to Fayol Management practices can be grouped into several patterns that can be identified and analyzed.

Management is the process of interpreting, coordinating resources, funding sources, and other sources to achieve goals and objectives through the actions of planning, organizing, mobilizing, supervision and assessment (Totok, 2004)

In managerial activities Henry Fayol (Fayol, 1963) suggests the functions Systematic management, which consists of:

1. Planning, in the form of determining the steps allows the organization to achieve its goals.

2. Organizing, in the sense of mobilizing material and material human resources to carry out the plan.

3. Governing commanding, giving directions to employees so can fulfill their job duties.

4. Coordinating ensuring resources and organizational activities take place harmoniously in achieving the goal.

5. Control monitoring plans to prove whether the plan has been implemented properly.

According to Fayol, there are at least 14 principles in organizational management, namely, (1) division duties, (2) authority and responsibility, (3) discipline, (4) unity of command, (5) coordination (unity of direction), (6) orderliness, (7) justice, (8) giving counter-achievement, (9) stability of tenure, (10) group unity, (11) rank levels, (12) initiative replacement of employees, (13) transfer of authority (centralization), (14) prioritization of public interests over personal interests (Fayol, 1963: 37). From these 14 principles by Henry Fayol, they were summarized into 4 names as a management function, namely, Planning, Organizing, Actuating, and Controlling the then shortened to POAC (Committee for the term management of PPM institutions, 1983) 


\section{Implementation of the Management of the Lksa Darul Hadlonah}

Orphanage Low Klaten. will be discussed in more detail as follows: Planning.

The management of the LKSA Darul Hadlonah Ceper Klaten orphanage has several planning programs, including:

a. LKSA Darul Hadlonah has a clear vision, mission and objectives.

b. The administrators of the LKSA Darul Hadlonah Ceper Klaten Orphanage compile a structured strategic plan systematic.

c. The management of the LKSA Darul Hadlonah Ceper Klaten Orphanage prepares an annual work and operational program plan.

d. Give love and affection that should and should usually obtained by children who get love and affection from his parents and family.

e. Establishing cooperative relationships with government agencies, educational, social, religious and community social institutions.

Organizing

The application of organizing is management function consisting of a series of co-operation, the act of dividing tasks, according to an interview with Ms. Rif'ah as the board of the orphanage on March 13, 2021, placing personnel and connecting among them them in order to create a harmonious atmosphere in carrying out something profession. As for the equipment, it is still limited to organizing personal according to the authority of each manager. However, there is still no visible effort to organize the equipment in detail.

Giving Commands

The leaders and administrators of the LKSA Darul Hadlonah Ceper Klaten Orphanage always give orders according to what has been set, and always try their best to give orders to foster children according to their respective abilities without coercion.

\section{Coordination}

Coordination at the orphanage has been running since the establishment of the orphanage, this is as evidenced by the existence of a division of labor between administrators and children foster. Regarding the management of the orphanage, it is determined and selected based on discussion.

Supervision or Controlling 
Leader along with the management of the LKSA Darul Hadlonah Ceper Klaten Orphanage basically have carried out supervision with good. Everything is always summarized in the form of a written report to be submitted to the leadership and reported annually, which is usually three months after the closing of the year.

\section{The Relevance of Henry Fayol's Managerial Practice Theory on the Implementation Management Orphanage of LKSA Darul Hadlonah Ceper Klaten}

Based on data analysis, either written data, statements, trends, or interpretations of matters relating to the relevance of implementing management elements with using Henri Fayol's perspective or point of view, which includes planning , organizing , command, coordinating , and controlling . The data would be processed through three streams of activities carried out simultaneously with each other, including; the process of data reduction, data presentation and conclusion or verification.

Meanwhile, the meaning of the research results will refer to the management elements theory of Henri Fayol, the relevant research results, the results of discussions with colleagues and the researchers' own reflections. The results of the discussion and interpretation of the research data then draw conclusions to provide input on the development of orphanage management, especially the LKSA Darul Hadlonah Ceper Klaten Orphanage. The relevance of Hery Fayol's managerial practice theory to the management of the LKSA Darul Hadlonah Ceper Klaten Orphanage. will be discussed more fully in the next section:

\section{Planning}

Based on interviews with the mother Ida, as the board of the orphanage LKSA Darul Hadlonah Ceper Klaten that the management plan tailored to the time period would be needed so that the implementation of the management plan can work well and on the determination allocation of time and weeks is effective. In the perspective of Henri Fayol (1963) explained that the planning is a diverse statements about opportunity and a way out. The preparing a plan is the most difficult and most important thing in every company, besides that it also plays a role in carrying out the functions of all divisions (Muslimin et al., 2021; Romlah $\&$ Latief, 2021), especially its management function. Therefore, the manager or leader must take a stand, namely by accepting suggestions from each division or 
member, coordinating and harmonizing their opinions. In the previous chapter, some of the plans that have been carried out by the LKSA Darul Hadlonah Ceper Klaten Orphanage are relevant because they have used methods modern planning that involve foster children, and the involvement of co-workers' management which is not only top down but also bottom up.

\section{Organizing}

Henri Fayol (1963) stated that organizing is providing something useful to carry out its functions, which include: materials, equipment, capital and personal, all of which must be divided into two parts, organizing equipment and organizing individuals. In the results of the interview, Linda said that being able to jointly be responsible with everything related to the utilization of facilities, equipment and personnel needed and able to form learning components in the institutional structure (Annur \& Suhono, 2019), forming an authority structure, determining and designing learning by organizing the allocation of time, media, methods.

It can be seen that in general the implementation of organizing carried out by the management of the LKSA Darul Hadlonah Ceper Klaten orphanage has been running smoothly, it can be seen from the leadership of the orphanage in arranging the division of labor to carry out its functions according to the expertise of the members and the purpose of establishing the orphanage. This is in line with Henri Fayol's theory, that organizing is by providing something useful for carrying out its functions, which include: materials, equipment, capital, models and personalities. However, it becomes less relevant based on the definition of organizing from Henri Fayol, that there are aspects that are not organized in the LKSA Darul Hadlonah Ceper Klaten Orphanage, namely, equipment. The management of the orphanage is still limited to organizing personally according to the authority of their respective administrators. However, there is still no visible effort to organize the equipment in detail.

\section{Giving Orders}

In the management process, the next activity that is carried out is a command, this activity is intended to give orders to all administrators so that it runs well because an organization must be formed and must be carried out. All that is described above, the LKSA Darul Hadlonah Ceper Klaten Orphanage also uses these methods, only that there are explained ways related to the company not about the orphanage, but from there it can be seen that the command carried out at 
the LKSA Darul Hadlonah Low Orphanage Klaten was similar to the theory presented by Henri Fayol, only they didn't know that what they were using was Henri Fayol's theory. That way, the LKSA Darul Hadlonah Orphanage Ceper Klaten could find out that the command that had been used was Henri Fayol's theory.

The results of the interview Ruli said that the members followed all the orders and instructions given by the leadership. Every movement that is good and effective is carried out by members and following the examples given by the leadership. From the description above, the leaders and administrators of the LKSA Darul Hadlonah Ceper Klaten Orphanage always give orders according to what has been set, and always try their best to give orders to foster children according to their respective abilities without coercion. This is in line with or relevant to Henri Fayol's theory that a manager or leader takes action to optimize the work of his subordinates and units.

\section{Coordination}

In an orphanage, coordinating with other parties is very necessary because without coordination the orphanage cannot stand alone. Meanwhile, in this study, coordination is defined as the activities of the LKSA Darul Hadlonah Ceper Klaten Orphanage in establishing coordination with other parties, especially in advancing the orphanage and keeping in touch with each other. Not only with other parties, the LKSA Darul Hadlonah Ceper Klaten Orphanage also coordinates with other administrators, so they help each other between divisions. This becomes relevant to Fayol's theory of ascertaining resources and organizational activities take place harmoniously in achieving the goal.

Supervision or Controlling

Supervision is the last function of the management process (Trihastuti, et al., 2021), this function is very important and determines the implementation of the process of an orphanage. In the interview, Ibu Indri said that in an activity, the supervision carried out the verification of whatever happened according to the agreed plan. Supervision aims to overcome weaknesses and problems by correcting and preventing these mistakes from being repeated. Supervision includes anything. Starting from infrastructure, people, in this case the workers, to the action or implementation. From the theory controling according to Fayol, the relevance of the application of leadership supervision along with the management of the LKSA Darul Hadlonah Ceper Klaten Orphanage basically have carried out 
supervision with good. Everything is always summarized in the form of a written report to be submitted to management and reported annually, which is usually three months after closing the year.

\section{Discussion}

The results of this study were reinforced by several previous finding Grissom, for insatnce J. A., Loeb, S., \& Mitani, H. (2015), in planning management, all programs related to the effectiveness and progress of the institution are the responsibility of all colleagues or teams in determining the allocation of time and work effectiveness (Bucăţa, G., \& Rizescu, 2017). Hence, the work results can be optimal. The work results will be reported through the administrative officer, so any problems regarding the implementation process that have problems will be reported so that they can be followed up or handled according to the problem solving that should be, such as if there is a manager who is unable to learn, it will be reported and transferred to a substitute teacher so that The learning process is still continuing, if there are problems with facilities or if there is media damage, it will be reported so that it is fixed again so that the learning process is not obstructed such as: blackboards, damaged props and reading books that are needed.

Other research Loucks, \& Van Beek, (2017), Wheelen, et al., (2017) also revealed that in planning on management must consider all components that influence each other, such as strategies, methods, or teacher teaching styles in determining success or achieving goals that contain learning objectives, teaching materials, teaching methods, learning resources, and assessment of learning outcomes. Planning management is a design so that learning is well carried out. adds that the learning planning that has been determined is carried out as much as possible to obtain success in learning (Karp, et al., 2016). As a manager, he must know or be able to develop it properly with the skills to carry it out so that it is in accordance with the objectives that are obtained.

In contrast, Al-Haddad, S., \& Kotnour, T. (2015) asserted that in the organizational aspect, especially the placement of personnel, is considered based on the graduate and the ability of an educator with regard to the subjects to be taught. In addition, every educator is assigned to carry out all disciplinary rules either to participants and leadership emphasized that organizing, which is about the division of duties of an educator, is the responsibility of the personnel (Kunter et al., 2013).Hence, So if you have been given authority to a task to carry out a 
good learning process, the task must be carried out. Furthermore, Mentang et al., (2013) said that all administrators must be responsible for everything such as: utilization of facilities, equipment and personnel needed to support the implementation of a program.

In the command aspect, it was in line with the findings of Batlajery, S. (2016), that every movement made by members must follow the examples given by the leadership. Accordingly, all decisions relating to the place of implementation. The members follow all the orders and instructions given by the leader. Every good and effective movement is carried out by members and following the examples given by the leadership. Graban, M. (2016) also emphasizes that using a strategy of giving orders to improve the quality of physical conditions through a variety of methods. Being wise in giving orders really helps to be more active in playing the role of a facilitator. In addition, the atmosphere is more focused on the material so that the goal can be achieved. In addition, it has an impact on the emergence of motivation for cooperation between members, who are equally active and creative. In the aspect of controlling, Selamet, M. (2017) asserted that management is supervision by monitoring the process. If there are some weaknesses in the implementation of work, it is necessary to provide tips or better ways to be able to create reliable participants in the form of training or workshops. Meanwhile, Fang et al., 2014 said that organizing by monitoring of the participants will face many kinds obstacles that were encountered during the activity process so that they could be overcome again.

\section{Conclusion}

After analyzing the data obtained, the researchers can draw conclusions from the research results as follows: The substance of Henri Fayol's theory, including planning, organizing , command or giving orders, coordinating, and controlling or supervision. The management of the LKSA Darul Hadlonah Ceper Klaten orphanage has similarities with management in Henri Fayol's perspective, both of which apply management elements which include planning, organizing, giving orders, coordination and supervision. It's just that they don't know that the pattern they are using is Henri Fayol's theory. The relevance of Henry Fayol's managerial practice theory on the management of the LKSA Darul Hadlonah Low Klaten Orphanage in the functions of planning, command or giving orders, coordinating, and controlling or supervision. Meanwhile, in the aspect of organizing, is still 
considered not relevant enough because the research results only answer the personal aspect.

In suggestion the leadership of the LKSA Darul Hadlonah Ceper Klaten Orphanage and the administrators always increase attention to the implementation of planning, organizing, giving orders, coordinating, and supervising the activities of the LKSA Darul Hadlonah Ceper Klaten Orphanage program in the future. Planning, it is hoped that the caregivers of LKSA Darul Hadlonah Ceper Klaten Orphanage, apart from receiving suggestions from fellow board members, should also be more open in accepting suggestions from foster children as stakeholders. Organizing, it is hoped that the facility and infrastructure division will carry out more of its role, namely organizing more detailed equipment, so that the organizing process runs smoothly. Giving orders, it is hoped that in giving orders to the leaders and administrators to be more firm and have authority so that foster children obey the rules and have full awareness of themselves. Coordination, it is hoped that coordination with fellow administrators will not only be carried out at the meeting table or forum, but also carried out more closely in their daily lives. Supervision, it is hoped that the LKSA Darul Hadlonah Ceper Klaten Orphanage will increase its supervisory staff so that in supervising foster children it is not overwhelmed and the supervision process can be maximized.

\section{Acknowledgement}

The authors wish to thank to participant, teacher, and the leader of of Lembaga Kesejahteraan Sosial Anak (LKSA) Darul Hadlonah Ceper Klaten were support for this research. Acknowledgments were also extended to all who contributed to this research. Thank you also expressed to all students for their contribution in helping collect data and in testing research book products. Thank for the team JMKSP (Jurnal Manajemen, Kepemimpinan, and Supervisi Pendidikan) that given suggestion in peer review process.

\section{References}

Aziz, M. N., \& Mohamad, O. B. (2016). Islamic Social Business to Alleviate Poverty and Social Inequality. International Journal of Social Economics.

Al-Haddad, S., \& Kotnour, T. (2015). Integrating the Organizational Change Literature: a Model for Successful Change. Journal of Organizational Change Management. 
Annur, S., \& Suhono, S. (2019). Implementasi Manajemen Perguruan Tinggi (Studi Kasus Pada PTKIS Kopertais Wilayah VII Sumatera Selatan) [Implementation of Higher Education Management (Case Study at PTKIS Kopertais Region VII South Sumatra)]. JMKSP (Jurnal Manajemen, Kepemimpinan, dan Supervisi Pendidikan), 4(1), 67-75.

Amrizal, A., Subandi, S., \& Fadillah, M. K. (2020). Effektivitas Taklim Remaja Islam Masjid dalam Membentuk Karakter Remaja di Era Industri 4.0 di Masjid Riyadus Sholihin [The Effectiveness of Muslim Youth Taklims in Mosques in Forming Youth Characters in the Industrial Era 4.0 at the Riyadus Sholihin Mosque]. Attractive: Innovative Education Journal, 2(1), $126-132$.

Bilal, M. W. (2003). Studi Kasus Model Penelitian dan Pemilihan Unit Penelitian [Case Study Research Model and Research Unit Selection]. Jurnal Hisbah. 2(1), 23-45

Batlajery, S. (2016). Penerapan Fungsi-Fungsi Manajemen Pada Aparatur Pemerintahan Kampung Tambat Kabupaten Merauke [Implementation of Management Functions in the Government Apparatus of Kampung Tambat, Merauke Regency]. Jurnal Ilmu Ekonomi \& Sosial, 7(2), 135-155.

Bucăţa, G., \& Rizescu, A. M. (2017). The Role of Communication in Enhancing Work Effectiveness of an Organization. Land Forces Academy Review, 22(1), 49-57.

Cahyono, H., Suhono, S., \& Khumairo, A. (2018). Pendidikan Karakter Bagi Pelaku Pedofilia (Sebuah Strategi dalam Mengatasi Amoral) [Character Education for Perpetrators of Pedophilia (A Strategy in Overcoming Immorality)]. JMKSP (Jurnal Manajemen, Kepemimpinan, dan Supervisi Pendidikan), 3(1), 1-19.

Fayol, H. (1963). General and Industrial Management. London: Sir Isaac Pitman \& Sons Ltd,

Fang, S., Da Xu, L., Zhu, Y., Ahati, J., Pei, H., Yan, J., \& Liu, Z. (2014). An Integrated System for Regional Environmental Monitoring and Management Based on Internet of Things. IEEE Transactions on Industrial Informatics, 10(2), 1596-1605.

Fu, H., \& Liu, X. (2017). A Study on the Impact of Environmental Education on Individuals' Behaviors Concerning Recycled Water Reuse. Eurasia Journal of Mathematics, Science and Technology Education, 13(10), 6715-6724. 
Gamayuni, R. R. (2018). The Effect of Good University Governance, Effectiveness of Internal Controlling System, and Obedience of Accounting Regulation on the Tendency of Fraud in PTKIN-BLU-similarity checked.

Gifford, R., \& Nilsson, A. (2014). Personal and Social Factors that Influence Pro-Environmental Concern and Behaviour: A Review. International Journal of Psychology, 49(3), 141-157.

Grissom, J. A., Loeb, S., \& Mitani, H. (2015). Principal Time Management Skills. Journal of Educational Administration.

Graban, M. (2016). Lean Hospitals: Improving Quality, Patient Safety, and Employee Engagement. CRC press.

Hezri, A. A., \& Dovers, S. R. (2013). 13 Shifting the Policy Goal From Environment to Sustainable Development. Malaysia's Development Challenges: Graduating From The Middle, 11, 276

Irianisyah, S., Harapan, E., \& Houtman, H. (2020). Supervisi Kepala Sekolah Dalam Penggunaan Media Pembelajaran di Sekolah Dasar [Supervision of Principals in the Use of Learning Media in Elementary Schools]. Attractive: Innovative Education Journal, 2(3), 1-7.

Karp, M. J. M., Kalamkarian, H. S., Klempin, S. C., \& Fletcher, J. (2016). How Colleges Use Integrated Planning and Advising for Student Success (iPASS) to Transform Student Support

Kunter, M., Klusmann, U., Baumert, J., Richter, D., Voss, T., \& Hachfeld, A. (2013). Professional Competence of Teachers: Effects on Instructional Quality and Student Development. Journal of Educational Psychology, 105(3), 805.

Loucks, D. P., \& Van Beek, E. (2017). Water Resource Systems Planning and Management: an Introduction to Methods, Models, and Applications. Springer.

Masduki, H., \& Masduki, H. (2020). Pemberdayaan Yatim Berdasarkan NilaiNilai Al-Qur'an Dalam Pengelolaan Panti Asuhan Pimpinan Daerah Muhammadiyah Kabupaten Pamekasan [Empowerment of Orphans based on Al-Qur'an Values in the Management of the Muhammadiyah Regional Leadership Orphanage in Pamekasan Regency]. Al-Irfan: Journal of Arabic Literature and Islamic Studies, 3(1), 88-105.

Mentang, M. I. F., Tjakra, J., Langi, J. E. C., \& Walangitan, D. R. O. (2013). Evaluasi Penerapan Sistem Manajemen Keselamatan dan Kesehatan Kerja pada Peningkatan Fasilitas PT. Trakindo Utama Balikpapan [Evaluation of 
the Implementation of the Occupational Safety and Health Management System for the Improvement of PT. Trakindo Utama Balikpapan]. Jurnal Sipil Statik, 1(5).

Muslimin, E., Fajrussalam, H., Syah, M., \& Erihadiana, M. (2021). The Implementation of Educational Facilities and Infrastructure Management in Supporting Learning Process during Pandemic Covid-19 (Study at SMA Plus As-Salaam Bandung). Bulletin of Science Education, 1(2), 116-123.i

Nawawi, H. (2005). Manajemen Strategik Organisasi Non Profit Bidang Pemerintahan [Strategic Management of Governmental Non-Profit Organizations]. Yogyakarta: Gadjah Mada University Press.

Prastowo, A. (2014). Metode Penelitian Kualitatif: dalam Perspektif Rancangan Penelitian [Qualitative Research Methods: in a Research Design Perspective]. Yogjakarta: Ar-Ruzz Media.

Ruliana, P. (2014). Komunikasi Organisasi:Teori dan Studi Kasus [Organizational Communication: Theory and Case Studies]. Jakarta: PT Raja Grafindo Persada.

Romlah, O. Y., \& Latief, S. (2021). Empowering the Quality of School Resources in Improving the Quality of Education. Bulletin of Science Education, 1(1), 37-41.

Selamet, M. (2017). Pengaruh Kompetensi Supervisi Manajerial Dan Supervisi Akademik Pengawas Sekolah Terhadap Kinerja Guru (Studi Deskriptif Kuantitatif pada SMP Negeri di Kota Banjar) [The Effect of Managerial Supervision Competencies and Academic Supervision of School Supervisors on Teacher Performance (Quantitative Descriptive Study at Public Junior High Schools in Banjar City)]. Administrasi Pendidikan: Jurnal Ilmiah Mahasiswa Pascasarjana, 2(1), 73-86.

Sugiyono. (2016). Metode Penelitian Kuantitatif, Kulatitatif dan $R \& D$ [Quantitative Research Methods, Qualitative and $R$ \& D]. Bandung: Alfabeta.

Sukmadinata, N. S. (2013) Metode Penelitian Pendidikan [Educational Research Methods]. Bandung: PT Remaja Rosdakarya.

Tampubolon, J. (2020). Supervisi Korektif untuk Menemukan KekuranganKekurangan Guru Kelas dalam Malaksanakan Pembelajaran di SD Negeri 173105 Tarutung [Corrective Supervision to Find Shortcomings of Classroom Teachers in Implementing Learning at SD Negeri 173105 Tarutung]. Attractive: Innovative Education Journal, 2(2), 133-140. 
Tengko, F., Limbong, M., \& Kailola, L. G. (2021). Pengaruh Supervisi Akademik Pengawas Sekolah Terhadap Kinerja Guru SMP di Kecamatan Tondon Kabupaten Toraja Utara [The Influence of School Supervision Academic Supervision on Junior High School Teacher Performance in Tondon District, North Toraja Regency]. Attractive: Innovative Education Journal, 3(1), 13-23.

Trihastuti, M., Latief, S., \& Kholid, M. R. (2021). The Influence of Teachers' Leadership and Motivation on Social Science Learning Outcomes MA Yahisha Cihampelas Bandung. Bulletin of Science Education, 1(2), 136144.

Totok Djuroto. (2004). Manajemen Penerbitan Pers [Press Publishing Management]. Bandung: Rosda Karya.

White, D. (2003). Social Policy and Solidarity, Orphans of the New Model of Social Cohesion. Canadian Journal of Sociology/Cahiers Canadiens De Sociologie, 51-76.

Wheelen, T. L., Hunger, J. D., Hoffman, A. N., \& Bamford, C. E. (2017).

Strategic Management and Business Policy (p. 55). Boston, MA: pearson.

Yayasan Badan Wakaf dan Kesejahteraan Muslimat NU Wilayah Kerja II Klaten Darul Hadlonah. (2010). Profil Panti Asuhan Darul Hadlonah, Klaten.

Zaidi, S. A. H., Wei, Z., Gedikli, A., Zafar, M. W., Hou, F., \& Iftikhar, Y. (2019). The Impact of Globalization, Natural Resources Abundance, and Human Capital on Financial Development: Evidence From Thirty-One OECD Countries. Resources Policy, 64, 101476. 